\title{
TYPY PRZEBIEGU PENTADOWYCH WSPÓŁCZYNNIKÓW STANU WODY JEZIOR NIŻU POLSKIEGO
}

\author{
KATARZYNA PLEWA \\ Uniwersytet im. Adama Mickiewicza w Poznaniu, \\ Wydział Nauk Geograficznych i Geologicznych, Zakład Hydrologii i Gospodarki Wodnej \\ ul. B. Krygowskiego 10, 61-680 Poznań
}

\begin{abstract}
The purpose of the research is to determine the types of course of the coefficients of water stages on pentads on the hydrological year.

The research distinguishes five main types and seven subtypes of pentad coefficients of the water stages of lakes in Poland in the average annual cycle. For the analysis, the daily values of water levels of 75 lakes located in the Polish Lowlands in years 1976-2015 were used. The data were obtained from the Institute of Meteorology and Water Management - National Research Institute. For each lake, the coefficient of water stages, for all 73 pentads of the hydrological year, was calculated. Pentadic values of water stage coefficients were the basis for hierarchical grouping of the lakes using Ward's method. On the basis of dendrogram analysis, 5 main groups of lakes with a different coefficient of water storage in the annual cycle were distinguished - so-called types of the course of pentad coefficient of water stages. The types distinguished differ in the beginning, end and duration of high and low water stages, as well as the variability of the coefficient of water stage in pentads of the hydrological year. Type 1 - with a small range of $\mathrm{W}$ coefficient parameter changes throughout the year is characteristic of coastal lakes, in type 2 lakes, high water stages are observed in the summer-autumn period, low stages in spring. In the remaining types, high water stages are usually observed in spring and low in the summer-autumn period.
\end{abstract}

Keywords: coefficient of water stage, hydrological regime, hierarchical grouping by Ward, lake, Poland

\section{WSTĘP}

Zmiany stanów wody jezior mają różny charakter i przyczyny. Z punktu widzenia funkcjonowania zbiornika wodnego istotne są zarówno zmiany krótkookresowe, sezonowe, jak i wieloletnie. W badaniach reżimu stanów wody jezior, tj. prawidłowości zmienności stanów wody w przeciętnym cyklu rocznym, ważne jest rozpoznanie sezonowych wahań stanów wody na podstawie możliwie długich serii obserwacyjnych. Do przyczyn wahań stanów wody w cyklu rocznym zalicza się głównie wielkość zasilania, na którą wpływają opady atmosferyczne, charakter przepływowości, dopływ i odpływ wody, związek jeziora $\mathrm{z}$ wodami podziemnymi, temperatura powietrza, a także fizjografia zlewni jeziornej, morfometria jeziora, jego geneza oraz działalność człowieka.

Problematyka wahań stanów wody jezior w Polsce podejmowana była często i dotyczyła pojedynczych jezior (Chlost, Cieśliński 2005), kilku, kilkunastu jezior (Skibniewski 1954; Pasławski 1975; Choiński 1985; Jańczak i Choiński 
1988; Plewa i in. 2015; Volchak i in. 2017) jezior położonych w północnowschodniej Polsce (Bajkiewicz-Grabowska 2001; Dąbrowski 2002; Górniak, Piekarski 2002), w północnej Polsce (Dąbrowski, Węglarczyk 2005), jezior Parku Narodowego Bory Tucholskie (Marszelewski i in. 2016), Wielkich Jezior Mazurskich (Dąbrowski 2001), jezior województwa podlaskiego (Górniak 2001), jezior zlewni rzeki Drawy (Kornaś, Krauze 2010) oraz większego zbioru jezior położonych na polskich pojezierzach (Borowiak 2000; Wrzesiński, Ptak 2016; Wrzesiński, Plewa 2016; Wrzesiński i in. 2017), a także jezior przybrzeżnych (Girjatowicz 2008, 2011). W polskiej literaturze limnologicznej brakuje jednak prac uogólniających zagadnienie zmian stanów wody w cyklu rocznym na podstawie analizy dużego zbioru jezior z możliwie długą i jednorodną serią obserwacyjną.

Na zmienność wahań w cyklu rocznym zwrócił uwagę m.in. Choiński (1985, 2007), który ze względu na wielkość amplitudy oraz rytm zmienności stanów wody wyznaczył pięć typów jezior (przybrzeżne, przepływowe, jeziora, z których wypływa ciek, bezodpływowe oraz górskie).

Celem pracy jest ustalenie typów przebiegu współczynnika stanu wody jezior Niżu Polskiego w pentadach roku hydrologicznego. Współczynnik stanu wody przedstawia przebieg wahań przeciętnych stanów wody jezior w cyklu rocznym. Został wprowadzony w 1957 r. przez M. Pardégo (Pardé coefficient) jako miesięczny współczynnik przepływu $(k)$ w klasyfikacji reżimu rzek. W pracy wprowadzono pojęcie pentadowego współczynnika stanu wody. Pozwoliło to na bardziej szczegółową analizę zmian stanów wody w cyklu rocznym. Współczynnik ten bardzo dobrze obrazuje charakter zmian średnich stanów miesięcznych względem wartości średniej wieloletniej. Pozwala na ustalenie, w których częściach roku stany wody są wyższe, a w których niższe niż wartości przeciętne, tj. pozwala na wyróżnienie okresów wysokich i niskich stanów wody i może być dobrym narzędziem w identyfikacji oraz charakterystyce typów reżimu stanów wody.

\section{OBSZAR I METODY BADAŃ}

W badaniach wykorzystano codzienne obserwacje stanów wody dla 75 jezior położonych w północnej części Polski (ryc. 1) z lat 1976-2015. Dane z lat 1976-1980 pochodzą z Roczników Hydrologicznych dorzecza Wisły i Odry. Stany wody z wielolecia 1981-2015 uzyskano ze zbiorów Instytutu Meteorologii i Gospodarki Wodnej - PIB. Dla 5 jezior (Bytyń Wielki, Dołgie, Komorze, Resko Przymorskie, Sławianowskie) z uwagi na brak danych analizowano lata 1981-2015.

Dla każdego jeziora obliczono współczynniki stanu wody $(W)$ dla wszystkich 73 pentad roku hydrologicznego. Współczynnik stanu wody jest stosunkiem 


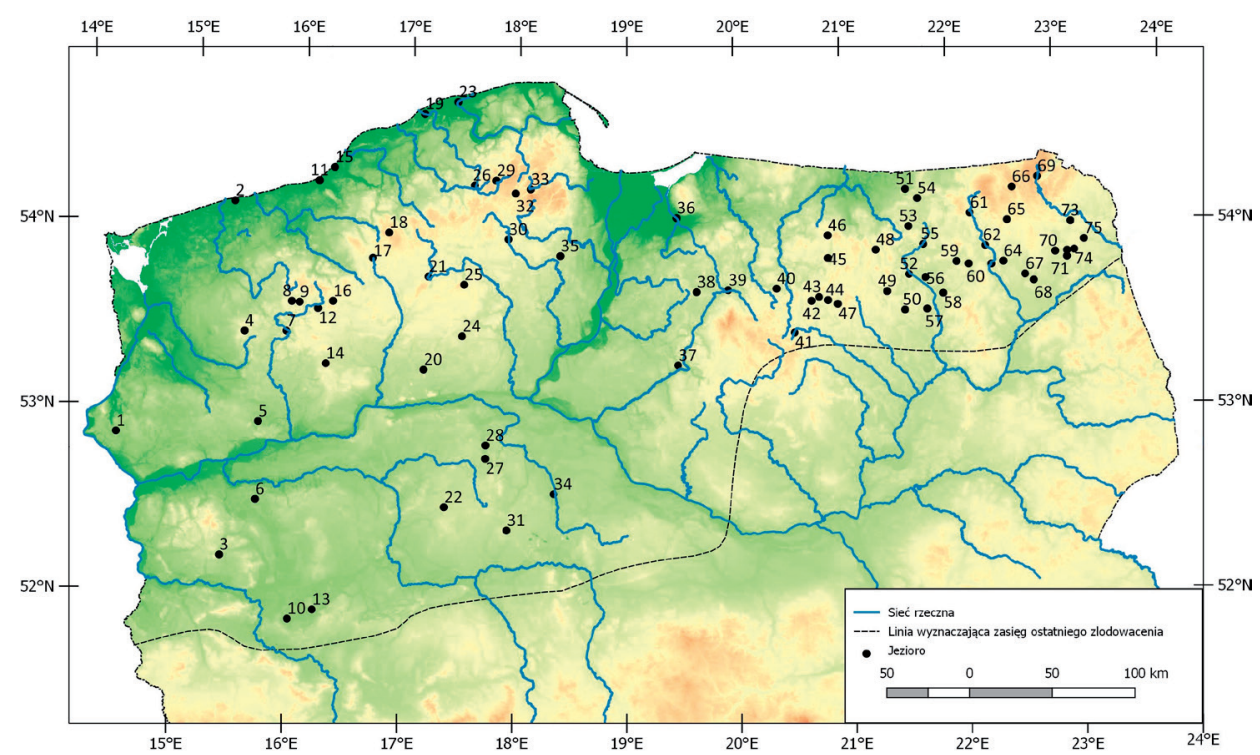

Ryc. 1. Lokalizacja badanych jezior (numeracja zgodna z tab. 1)

Fig. 1. Locations of the research lakes (the numbering of lakes as in Tab. 1)

średniego stanu wody w $n$-tej pentadzie $\left(H_{p_{n}}\right.$, gdzie $n$ wynosi $\left.1,2, \ldots, 73\right)$ do średniego stanu wody w analizowanym wieloleciu $\left(H_{1976-2015}\right)$.

$$
W=\frac{H_{p_{n}}}{H_{1976-2015}}[-]
$$

Zbiór 73 wartości $W$ był podstawą przeprowadzenia hierarchicznego grupowania jezior metodą Warda (1963). Grupowanie polega na łączeniu dwóch skupień, które po połączeniu zapewniają minimum sumy kwadratów odchyleń od środka ciężkości kolejnego (nowego) skupienia. Liczbę grup ustalono na podstawie analizy dendrogramu oraz krzywej odległości wiązania. Analizę przeprowadzono na dwóch poziomach grupowania. Na pierwszym poziomie przy odległości wiązania równej 20 wyróżniono 5 grup typologicznych jezior o podobnym przebiegu współczynnika stanu wody, a przy odległości wiązania równej 12 wyróżniono 9 grup. Łącznie przeanalizowano 5 głównych typów przebiegu współczynnika stanów wody oraz 7 podtypów (ryc. 2). Na obu poziomach grupowania typ 1 i 5 pozostał bez zmian, w typie 2 wydzielono podtypy $2 \mathrm{a}$ oraz $2 \mathrm{~b}$, w typie 3 - 3a, 3b, 3c, w typie 4 - 4a i 4b. Różnice między średnimi pentadowymi wartościami $W$ w poszczególnych typach w pentadach roku hydrologicznego sprawdzono za pomocą testu $t$ dla prób niezależnych. Jest to metoda powszechnie stosowana do oceny różnic pomiędzy średnimi w dwóch próbach (StatSoft, 2006). Wyniki testowania przedstawiono na rycinie 8. 
W pracy wykorzystano procedury statystyczne i graficzne programów Microsoft Excel, Statistica 13.1, Quantum GIS Las Palmas oraz Surfer 10 [Golden Software].

Tabela 1. Parametry morfometryczne badanych jezior

Table 1. Morphometric data of the studied lakes

\begin{tabular}{|c|c|c|c|c|c|c|}
\hline Lp. & Jezioro & $\begin{array}{l}\text { Powierzchnia* } \\
\text { [ha] }\end{array}$ & $\begin{array}{l}\text { Objętośćc } \\
\text { [tys. } \mathrm{m}^{3} \text { ] }\end{array}$ & $\begin{array}{l}\text { Średnia* } \\
\text { głębokość } \\
{[\mathrm{m}]}\end{array}$ & $\begin{array}{c}\text { Maksymalna* } \\
\text { głębokość } \\
{[\mathrm{m}]}\end{array}$ & $\begin{array}{l}\text { Średnia roczna } \\
\text { amplituda stanów } \\
\text { wody }[\mathrm{cm}]\end{array}$ \\
\hline 1 & Morzycko & 317,5 & 49826,9 & 14,5 & 60,7 & 35 \\
\hline 2 & Resko Przymorskie & 559,0 & 7703,4 & 1,3 & 2,5 & 110 \\
\hline 3 & Niesłysz & 526,0 & 34457,6 & 6,9 & 34,7 & 28 \\
\hline 4 & Ińsko & 529,0 & 65182,0 & 11,0 & 41,7 & 38 \\
\hline 5 & Osiek & 514,0 & 50065,0 & 9,3 & 35,3 & 32 \\
\hline 6 & Lubikowskie & 277,5 & 34842,1 & 10,9 & 35,5 & 40 \\
\hline 7 & Lubie & 1487,5 & 169880,5 & 11,6 & 46,2 & 40 \\
\hline 8 & Dołgie & 66,0 & 2049,2 & 3,4 & 8,1 & 23 \\
\hline 9 & Siecino & 740,0 & 104441,7 & 14,1 & 44,2 & 41 \\
\hline 10 & Sławskie & 822,5 & 42664,8 & 5,2 & 12,3 & 35 \\
\hline 11 & Jamno & 2231,5 & 31528,0 & 1,4 & 3,9 & 73 \\
\hline 12 & Drawsko & 1797,5 & 331443,4 & 17,7 & 82,2 & 47 \\
\hline 13 & Osłonińskie & 172,5 & 2858,0 & 1,6 & 3,0 & 40 \\
\hline 14 & Bytyń Wielki & 829,0 & 91534,9 & 0,4 & 41,0 & 26 \\
\hline 15 & Bukowo & 1644,0 & 32071,7 & 1,8 & 2,8 & 82 \\
\hline 16 & Komorze & 386,0 & 49372,0 & 11,8 & 34,7 & 21 \\
\hline 17 & Wierzchowo & 712,5 & 70212,5 & 9,6 & 26,5 & 46 \\
\hline 18 & Bobięcińskie Wielkie & 487,5 & 48985,2 & 9,1 & 48,0 & 38 \\
\hline 19 & Gardno & 2337,5 & 30950,5 & 1,3 & 2,6 & 88 \\
\hline 20 & Sławianowskie & 269,0 & 18303,7 & 6,6 & 15,0 & 46 \\
\hline 21 & Szczytno Wielkie & 565,0 & 51762,5 & 8,0 & 21,4 & 48 \\
\hline 22 & Lednica & 325,0 & 24397,0 & 7,0 & 15,1 & 58 \\
\hline 23 & Łebsko & 7020,0 & 117521,0 & 1,6 & 6,3 & 86 \\
\hline 24 & Sępoleńskie & 157,5 & 7501,6 & 4,8 & 10,9 & 43 \\
\hline 25 & Charzykowskie & 1336,0 & 134533,2 & 9,8 & 30,5 & 38 \\
\hline 26 & Jasień Pd. & 575,0 & 48048,0 & 8,3 & 32,2 & 17 \\
\hline 27 & Biskupińskie & 107,0 & 6397,2 & 5,5 & 13,7 & 38 \\
\hline 28 & Żnińskie Duże & 420,5 & 29492,6 & 6,8 & 11,1 & 74 \\
\hline 29 & Gowidlińskie & 381,0 & 30391,0 & 7,6 & 36,9 & 33 \\
\hline 30 & Wdzydze & 1417,0 & 220800,0 & 1,2 & 69,5 & 46 \\
\hline 31 & Powidzkie & 1097,5 & 134776,2 & 11,5 & 46,0 & 34 \\
\hline 32 & Raduńskie Górne & 362,5 & 60158,7 & 15,5 & 43,0 & 27 \\
\hline 33 & Ostrzyckie & 296,0 & 20785,2 & 6,7 & 21,0 & 35 \\
\hline 34 & Gopło & 2121,5 & 78497,0 & 3,6 & 16,6 & 87 \\
\hline
\end{tabular}




\begin{tabular}{|c|c|c|c|c|c|c|}
\hline 35 & Borzechowskie Wielkie & 240,0 & 27002,0 & 11,0 & 43,0 & 29 \\
\hline 36 & Druzno & 1147,5 & 17352,0 & 1,2 & 2,5 & 97 \\
\hline 37 & Bachotek & 215,0 & 15394,2 & 7,2 & 24,3 & 74 \\
\hline 38 & Jeziorak & 3152,5 & 141594,2 & 4,1 & 12,9 & 44 \\
\hline 39 & Drwęckie & 780,0 & 50140,1 & 5,7 & 22,0 & 59 \\
\hline 40 & Wulpińskie & 683,5 & 76990,3 & 10,5 & 54,6 & 45 \\
\hline 41 & Omulew & 504,0 & 22172,7 & 4,3 & 32,5 & 17 \\
\hline 42 & Kośno & 562,5 & 75767,3 & 13,7 & 44,6 & 23 \\
\hline 43 & Kalwa & 561,0 & 39468,6 & 7,0 & 31,7 & 33 \\
\hline 44 & Leleskie & 410,0 & 51789,5 & 12,1 & 49,5 & 29 \\
\hline 45 & Dadaj & 975,0 & 120784,2 & 12,0 & 39,8 & 71 \\
\hline 46 & Luterskie & 687,5 & 49824,5 & 7,2 & 20,7 & 51 \\
\hline 47 & Sasek Wielki & 866,0 & 71194,8 & 8,2 & 38,0 & 31 \\
\hline 48 & Juno & 347,5 & 45476,5 & 11,9 & 33,0 & 33 \\
\hline 49 & Mokre & 790,0 & 107334,0 & 12,7 & 51,0 & 29 \\
\hline 50 & Nidzkie & 1750,0 & 113872,3 & 6,2 & 23,7 & 31 \\
\hline 51 & Rydzówka & 500,0 & 30936,9 & 6,2 & 16,7 & 51 \\
\hline 52 & Mikołajskie & 424,0 & 55739,7 & 11,2 & 25,9 & 38 \\
\hline 53 & Dejguny & 762,5 & 92617,4 & 12,0 & 45,0 & 34 \\
\hline 54 & Mamry & 9851,0 & 1003367,5 & 9,8 & 43,8 & 39 \\
\hline 55 & Jagodne & 872,5 & 82705,2 & 8,7 & 37,4 & 39 \\
\hline 56 & Śniardwy & 11487,5 & 660211,8 & 5,8 & 23,4 & 38 \\
\hline 57 & Pogubie Wielkie & 649,0 & 7192,4 & 1,0 & 2,6 & 30 \\
\hline 58 & Roś & 1808,5 & 152924,9 & 8,1 & 31,8 & 88 \\
\hline 59 & Orzysz & 1012,5 & 75326,2 & 6,6 & 36,0 & 42 \\
\hline 60 & Druglin & 411,0 & 10203,0 & 2,4 & 6,4 & 42 \\
\hline 61 & Litygajno & 154,5 & 9763,9 & 6,0 & 16,4 & 74 \\
\hline 62 & Łaśmiady & 940,0 & 84607,8 & 9,6 & 43,7 & 58 \\
\hline 63 & Ełckie & 385,0 & 57420,3 & 15,0 & 55,8 & 60 \\
\hline 64 & Selmęt Wielki & 1207,5 & 99463,9 & 7,8 & 21,9 & 58 \\
\hline 65 & Olecko Wielkie & 205,0 & 37912,5 & 16,7 & 45,2 & 47 \\
\hline 66 & Rospuda Filipowska & 323,5 & 49731,8 & 14,5 & 38,9 & 30 \\
\hline 67 & Rajgrodzkie & 1499,0 & 142623,2 & 9,4 & 52,0 & 96 \\
\hline 68 & Dręstwo & 549,0 & 42734,6 & 8,5 & 25,0 & 96 \\
\hline 69 & Hańcza & 291,5 & 120364,1 & 38,7 & 106,1 & 50 \\
\hline 70 & Necko & 400,0 & 40561,4 & 10,1 & 25,0 & 46 \\
\hline 71 & Sajno & 494,0 & 52446,8 & 10,0 & 27,0 & 90 \\
\hline 72 & Białe Augustowskie & 452,5 & 41716,5 & 8,7 & 30,0 & 50 \\
\hline 73 & Wigry & 2115,0 & 336726,7 & 15,4 & 74,2 & 26 \\
\hline 74 & Studzieniczne & 244,0 & 22073,6 & 8,7 & 30,5 & 22 \\
\hline 75 & Serwy & 438,5 & 67181,5 & 14,1 & 41,5 & 43 \\
\hline
\end{tabular}

* Opracowano na podstawie Katalogu jezior Polski (Choiński 2006). 

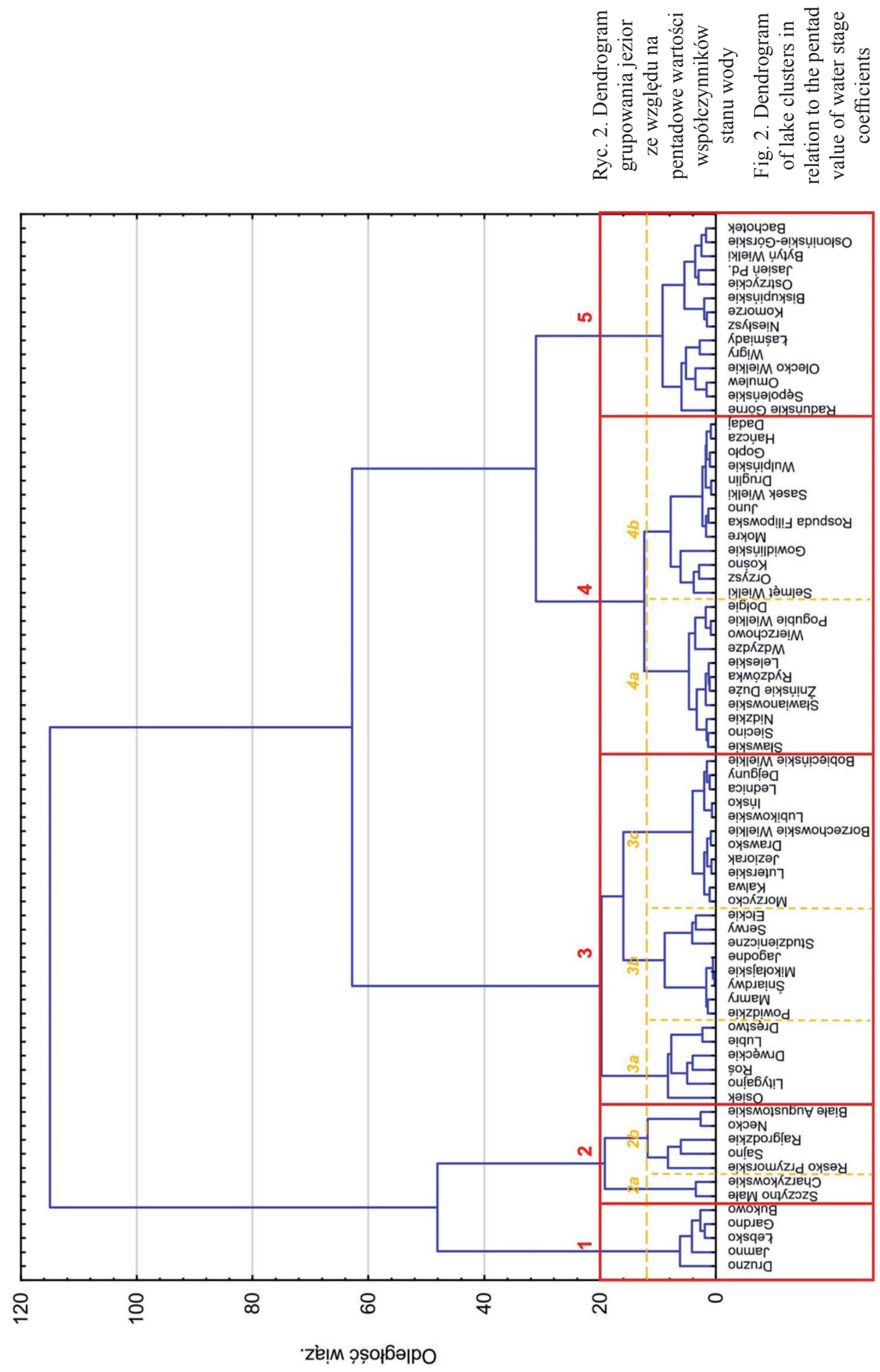


\section{WYNIKI}

Typ 1 przebiegu współczynników stanu wody $W$ jest charakterystyczny dla jezior przybrzeżnych (Druzno, Jamno, Łebsko, Gardno, Bukowo) - ryciny 2 i 3. Wysokie stany wody ( $W>1$ ) obserwuje się w lipcu (czas trwania ok. 15 dni) oraz od września do lutego (180 dni) - rycina 4, zazwyczaj podczas sztormów, gdy występują wlewy wody morskiej do jezior. Niskie stany wody $(W<1)$ występują od końca lutego do pierwszej połowy lipca (ok. 140 dni). Zakres zmian stanów wody jest niewielki. Współczynniki stanu wody wahają się od 0,971 do 1,021 . Maksymalna wartość współczynnika $W$ może dochodzić do 1,027 , natomiast minimalna do 0,965 .

Typ 2 skupia jeziora o największych zmianach stanów wody w cyklu rocznym (Szczytno, Charzykowskie, Resko Przymorskie, Sajno, Rajgrodzkie, Necko oraz Białe Augustowskie) - ryciny 2 i 3 . Na jeziorach tych niskie stany wody obserwuje się od końca października do marca. Najniższe stany wody zazwyczaj występują na początku marca $(W=0,895)$. Wysokie stany wody obserwowane są w okresie letnio-jesiennym (95 dni) - przeciętna wartość współczynnika stanu wody wynosi 1,064 w lipcu. Najniższy współczynnik stanu wody może dochodzić do 0,677 na przełomie maja i czerwca (w 43. pentadzie roku hydrologicznego) na Jeziorze Charzykowskim, natomiast najwyższy 1,346 w drugiej połowie września (65. pentada), również na tym jeziorze.

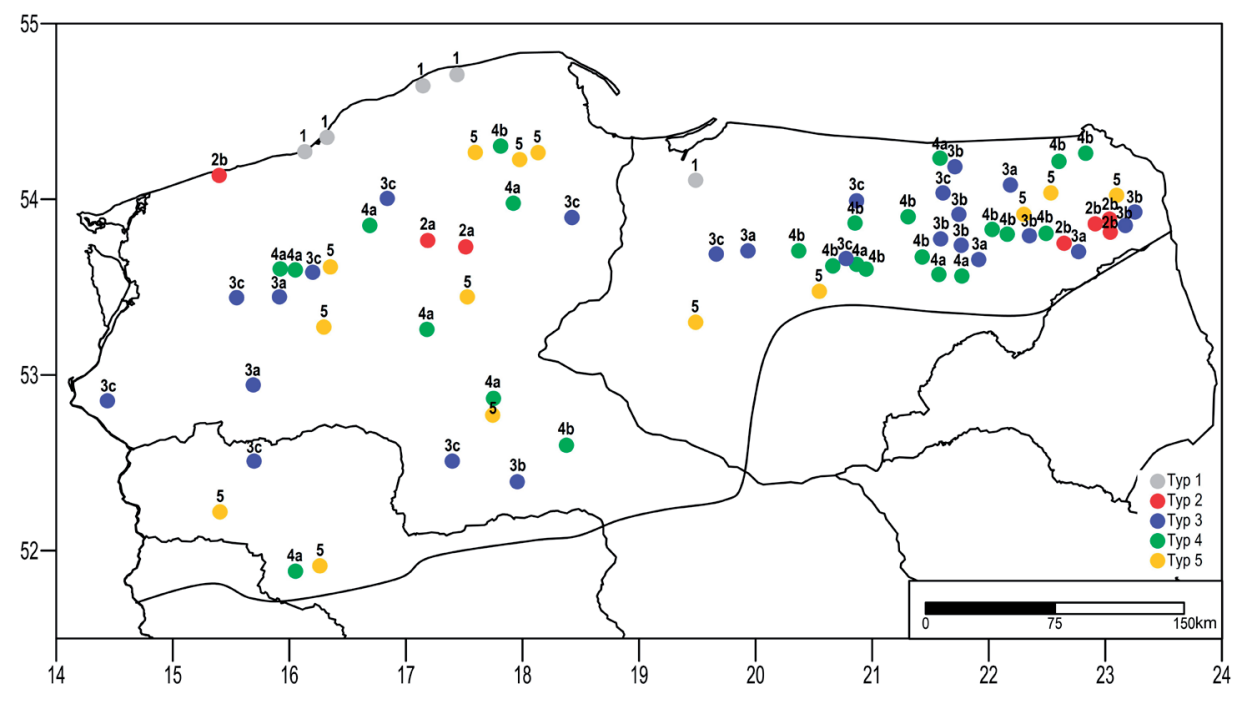

Ryc. 3. Położenie jezior reprezentujących wyróżnione typy przebiegu współczynnika stanu wody w cyklu rocznym

Fig. 3. Location of lakes representing the distinguished types of water stage coefficient in an annual cycle 
Typ 1

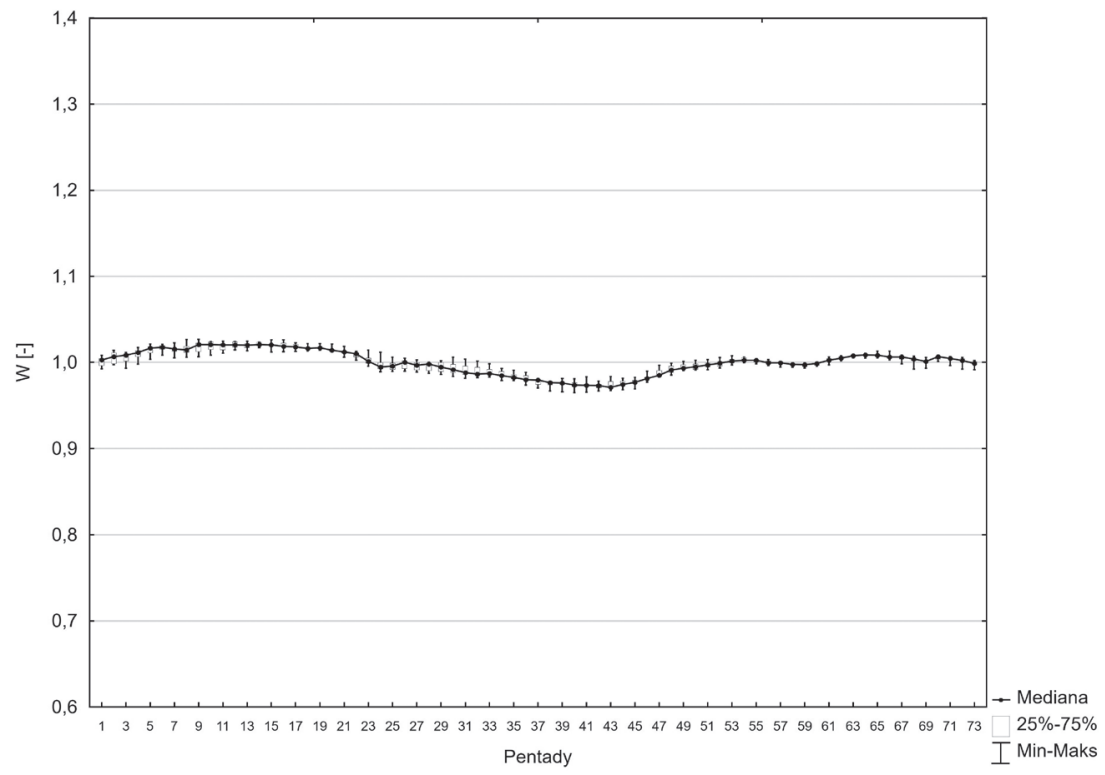

Ryc. 4. Zakres zmian pentadowych współczynników stanu wody jezior w typie 1

Fig. 4. Range of changes of pentad water stage coefficients in type 1 lakes

Na jeziorach w podtypie 2a (Szczytno i Charzykowskie) współczynnik stanu wody ma charakterystyczny przebieg. Wysokie stany wody obserwowane są w okresie letnio-jesiennym przez około 140 dni. Najwyższy współczynnik stanu wody może dochodzić do 1,346 w drugiej połowie września. Niskie stany wody występują zazwyczaj przez $220 \mathrm{dni}$ w roku, a najniższe $(W=0,677)$ przypadają na przełom maja i czerwca. Przeciętne stany wody $(W=1)$ zaobserwowano w drugiej połowie listopada (trwały ok. 5 dni.) - rycina 5.

W podtypie 2b, do którego zaliczono jeziora: Resko Przymorskie, Sajno, Rajgrodzkie, Necko i Białe Augustowskie, wysokie stany wody na jeziorach obserwowane są wcześniej niż w podtypie 2a, tj. na przełomie marca i kwietnia, a w podtypie 2a w lipcu. Wysokie stany wody trwały 185 dni, niskie zaś 160 dni w roku. Maksymalne wartości współczynnika stanu wody dochodzą do $1,188 \mathrm{w}$ pierwszej połowie kwietnia, minimalne osiągają 0,857 pod koniec lutego (ryc. 5).

Do typu 3 zaliczono 25 jezior (ryc. 2, 3). Położone są one na wszystkich pojezierzach, podobnie jak w typach 4 i 5 . Na niższym poziomie grupowania wyznaczono 3 podtypy przebiegu współczynników stanu wody - ryciny 2 i 6 .

W typie 3 wysokie stany wody obserwuje się od stycznia do lipca (ok. 180 dni), najwyższe stany wody występują wiosną, w kwietniu $(W=1,083)$. Maksymalna wartość współczynnika $W$ dochodzi do 1,224 w pierwszej połowie 


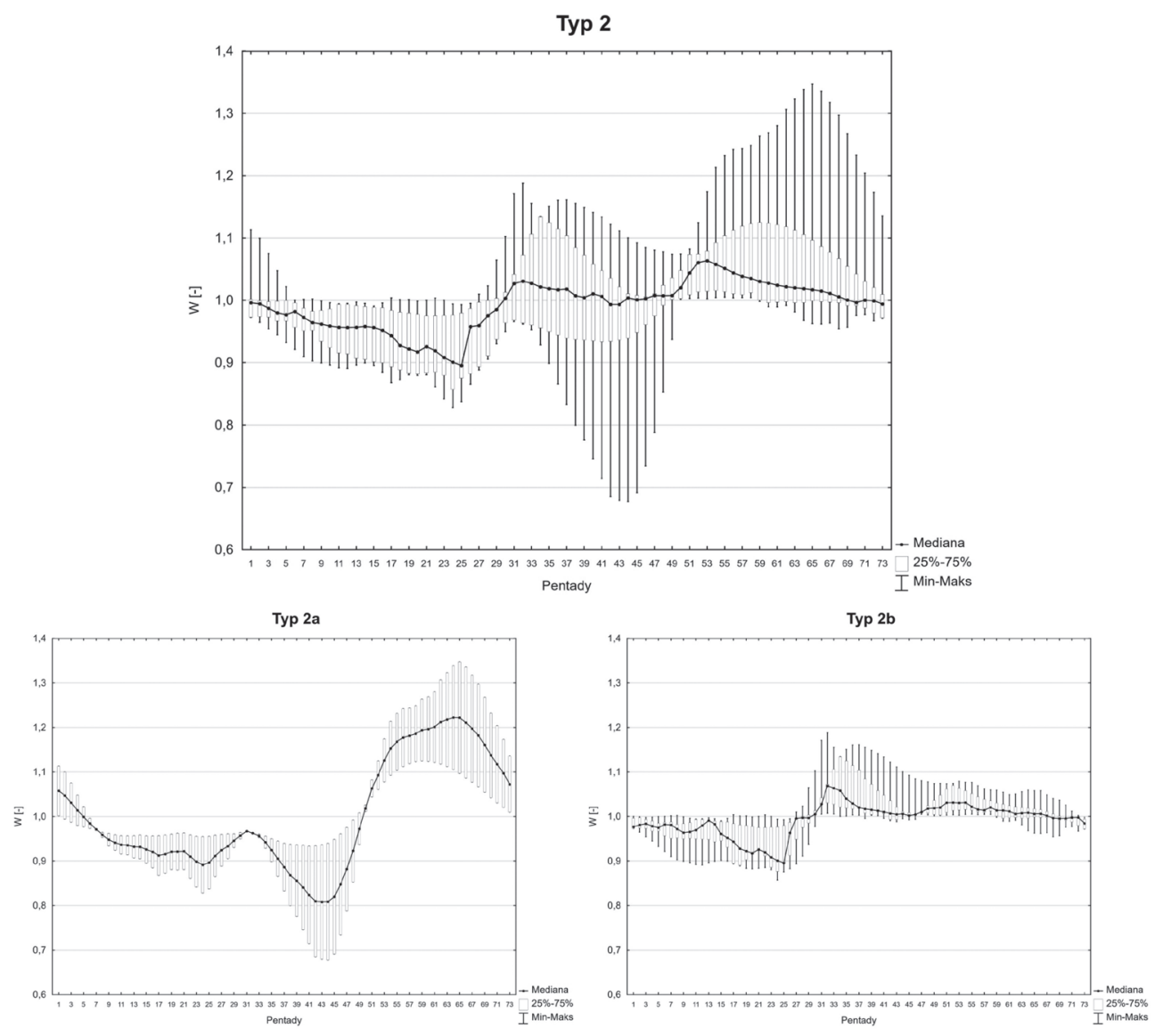

Ryc. 5. Zakres zmian pentadowych współczynników stanu wody jezior w typie 2

Fig. 5. Range of changes of pentad water stage coefficients in type 2 lakes

kwietnia (33, pentada), natomiast minimalna $W=0,791$ pod koniec listopada (5. pentada) - rycina 6.

Do podtypu 3a zaliczono 6 jezior: Osiek, Litygajno, Roś, Drwęckie, Lubie, Dręstwo (ryc. 2, 3). Wysokie stany wody $(W>1)$ występują od drugiej połowy stycznia (16, pentada) do drugiej połowy maja oraz na przełomie lipca i sierpnia. W sumie przez 155 dni w roku. Najwyższe stany obserwuje się w połowie kwietnia $(W=1,06)$, natomiast najniższe $(W=0,95) \mathrm{w}$ listopadzie. Maksymalne wartości mogą dochodzić do 1,14 wiosną, minimalne do 0,791 na przełomie jesieni i zimy.

Do podtypu 3b zaklasyfikowano 8 jezior: Powidzkie, Mamry, Śniardwy, Mikołajskie, Jagodne, Studzieniczne, Serwy, Ełckie - ryciny 2 i 3 . W podtypie 3b wysokie stany wody obserwuje się od pierwszej połowy lutego do pierwszej 


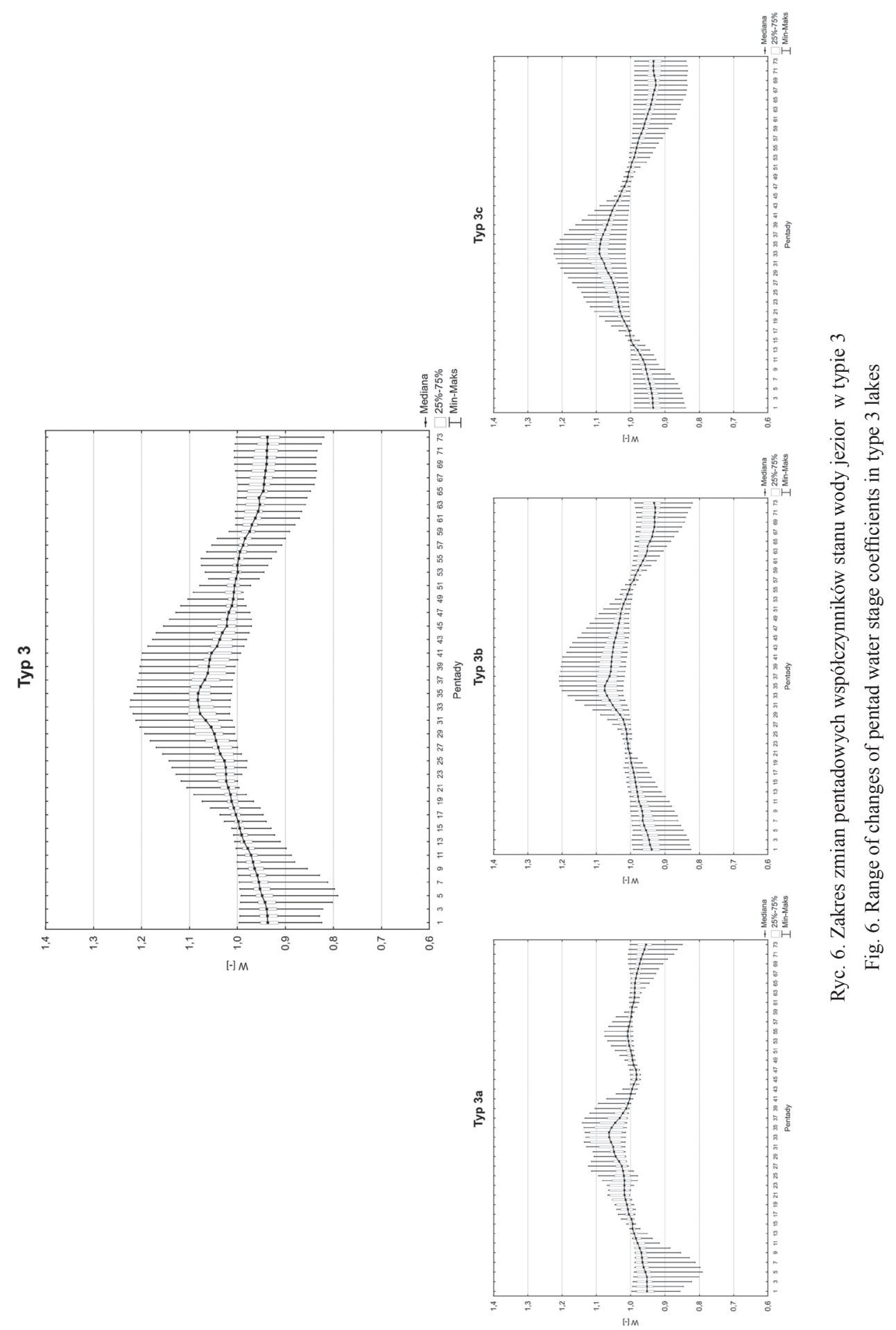


połowy sierpnia (ok. 180 dni). Najwyższy współczynnik stanu wody wystąpił w drugiej połowie kwietnia $(W=1,076)$. Niskie stany wody odnotowuje się w okresie jesienno-zimowym. W październiku przeciętna wartość współczynnika stanu wody była najniższa i wynosiła 0,929 . Maksimum wystąpiło pod koniec kwietnia $(W=1,209)$, natomiast minimum w ostatniej pentadzie roku hydrologicznego $(W=0,819)$. Na jeziorach w podtypie $3 \mathbf{b}$ wysokie stany wody występują później niż w podtypie 3a (o 20 dni).

W podtypie 3c wyróżniono 11 jezior: Morzycko, Kalwa, Luterskie, Jeziorak, Drawsko, Borzechowskie Wielkie, Lubikowskie, Ińsko, Lednica, Dejguny, Bobięcińskie Wielkie - ryciny 2 i 3 . Wysokie stany wody na jeziorach $(W>$ 1) występują wcześniej niż w podtypach 3a i 3b. Rozpoczynają się około 20 stycznia (17. pentada) i trwają do pierwszej połowy lipca, przez około 170 dni. Najwyższe stany obserwuje się od 10 do 19 kwietnia (podobnie jak w typie 3a), ale przeciętny współczynnik stanu wody jest wyższy i wynosi 1,091. Niskie stany wody odnotowuje się w okresie letnio-jesiennym. Najniższe przeciętne stany wody $(W=0,927)$ obserwuje się na początku października. Maksimum wynosi $1,224 \mathrm{w}$ pierwszej połowie kwietnia (33. pentada), minimum $0,83 \mathrm{w}$ drugiej połowie października (73. pentada).

Do typu 4 zaliczono 24 jeziora (ryc. 2, 3). Wysokie stany wody obserwowane są od początku stycznia do początku czerwca i trwają około 160 dni. Najwyższe stany pojawiają się w drugiej połowie kwietnia, $W=1,074$ (33. pentada). Niskie stany wody występują zazwyczaj od drugiej połowy czerwca do stycznia, a najniższe $(W=0,943)$ na początku października.

Podtyp 4a obejmuje 11 jezior: Sławskie, Siecino, Nidzkie, Sławianowskie, Żnińskie Duże, Rydzówka, Leleskie, Wdzydze, Wierzchowo, Pogubie Wielkie, Dołgie (ryc. 2, 3). W podtypie 4a wysokie stany wody ( $W>1$ ) obserwuje się od początku stycznia (13. pentada) do pierwszej połowy czerwca (45. pentada) przez około 180 dni. Najwyższe stany wody, współczynnik stanu wody jest równy 1,08 , są obserwowane w pierwszej połowie kwietnia. Niskie stany wody $(W<1)$ występują na przełomie czerwca i lipca (49. pentada), do drugiej połowy grudnia (ok. $170 \mathrm{dni}$ ). W pozostałe dni (ok. 15) obserwuje się przeciętne stany wody, współczynnik stanu wody jest równy 1,00 . Maksymalne wartości współczynnika $W$ mogą dochodzić do 1,22 na początku kwietnia (31. pentada), minimalne natomiast do 0,78 we wrześniu i październiku (ryc. 7).

Podtyp 4b charakteryzuje się tym, że wysokie stany wody można obserwować od drugiej połowy stycznia (10 dni później niż w podtypie 4a) do przełomu maja i czerwca (ryc. 7). Trwają one około 145 dni, czyli około miesiąc krócej niż w podtypie 4a. Najwyższy przeciętny współczynnik stanu wody $(W=1,073)$ został zaobserwowany na przełomie marca i kwietnia (31. pentada). Niskie stany wody rozpoczynają się w połowie czerwca (46. pentada) i trwają do pierwszej połowy grudnia (ok. 185 dni), czyli dłużej niż w podtypie 4a. Najniższe stany występują ( $W=0,958)$ na początku września (63. pentada). Maksimum 


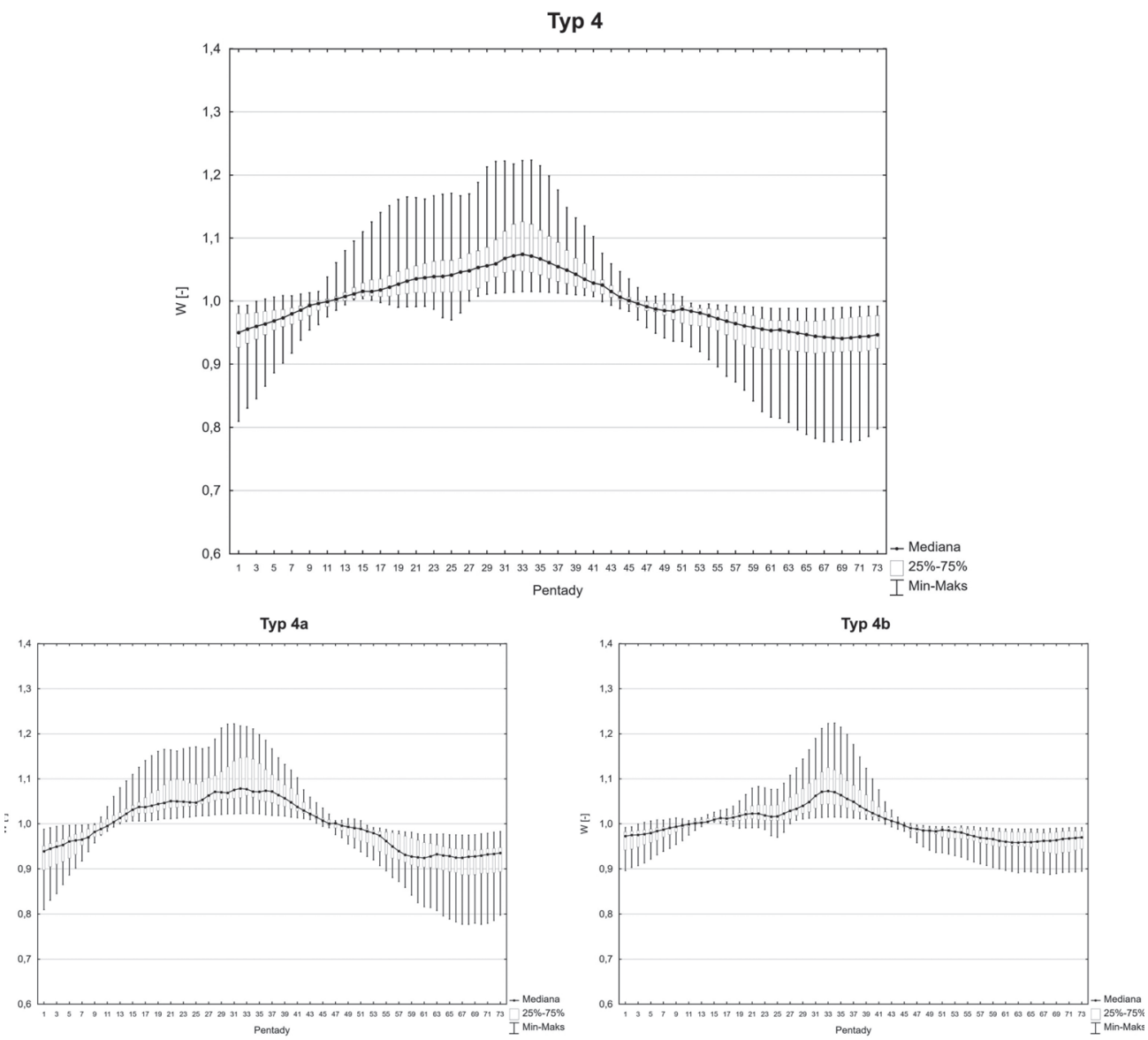

Ryc. 7. Zakres zmian pentadowych współczynników stanu wody jezior w typie 4

Fig. 7. Range of changes of pentad water stage coefficients in type 4 lakes

stanów ( $W=1,22)$ przypada na połowę kwietnia (34. pentada), natomiast minimum $(W=0,889)$ na pierwszą połowę października (68. i 69. pentada). Do podtypu 4b zaliczono 13 jezior: Selmęt Wielki, Orzysz, Kośno, Gowidlińskie, Mokre, Rospuda Filipowska, Juno, Sasek Wielki, Druglin, Wulpińskie, Gopło, Hańcza i Dadaj - ryciny 2 i 3.

Do typu 5 zaliczono 14 jezior: Raduńskie Górne, Sępoleńskie, Omulew, Olecko Wielkie, Wigry, Łaśmiady Niesłysz, Komorze, Biskupińskie, Ostrzyckie, Jasień, Bytyń Wielki, Osłonińskie Górskie, Bachotek (ryc. 2, 3). Przeciętne wartości współczynnika $W$ wahają się od 0,96 jesienią (wrzesień, październik) do ponad $1,05 \mathrm{w}$ kwietniu. Wyraźny spadek stanów wody następuje w czerwcu. Wysokie stany wody obserwuje się od pierwszej połowy grudnia (8. pentada) do drugiej połowy maja (41. pentada), około 170 dni. Najwyższe stany zanotowano w kwietniu 
(32. pentada), $W=1,064$. Współczynnik stanu wody poniżej 1 obserwowany jest od przełomu maja i czerwca (43. pentada) do drugiej połowy listopada (5. pentada). Najniższe stany zazwyczaj występują na początku października $(W=0,955)$. Maksima $(W=1,17)$ obserwowane są na przełomie marca i kwietnia (30. i 31 . pentada), minima ( $W=0,877)$ na początku października (68. pentada) - rycina 8 .

Pomiędzy wartością pentadowych współczynników stanu wody w poszczególnych typach obserwuje się istotne statystycznie różnice (ryc. 9). Największe różnice w przebiegu i wartości pentadowych współczynników stanu wody odnotowuje się między typami: 2 i 4 (305 dni), 1 i 4 oraz 2 i 3 (295 dni), 1 i 5 (280 dni), 2 i 5 (250 dni) oraz 3 i 5 (245 dni).

Przeciętne stany wody w typie 2 różnią się istotnie statystycznie od przeciętnych stanów wody w typie 1 przez 230 dni w roku (36\%), a w typie 3 - 270 dni (74\%). Typ 3 różni się istotnie statystycznie wysokością pentadowych współczynników stanu wody od typu 1 przez 270 dni w roku (74\%), a od typu 2 przez 295 dni (81\%). W typie 4 przeciętne wartości $W$ różnią się istotnie statystycznie od $W$ w typie 1 przez $74 \%$ dni w roku, od typu 2 przez $84 \%$, a od typu $3-48 \%$. Obserwuje się istotne statystycznie różnice pomiędzy typem $\mathbf{5}$ a pozostałymi typami $(1,2,3,4)$. Największe różnice między przeciętnymi wartościami $W$ zanotowano w typach 1 i 5 (77\% - 280 dni) oraz typach 2 i $5(68,5 \%-250$ dni). W przypadku tych grup największe różne obserwuje się na początku roku.

Typ 5

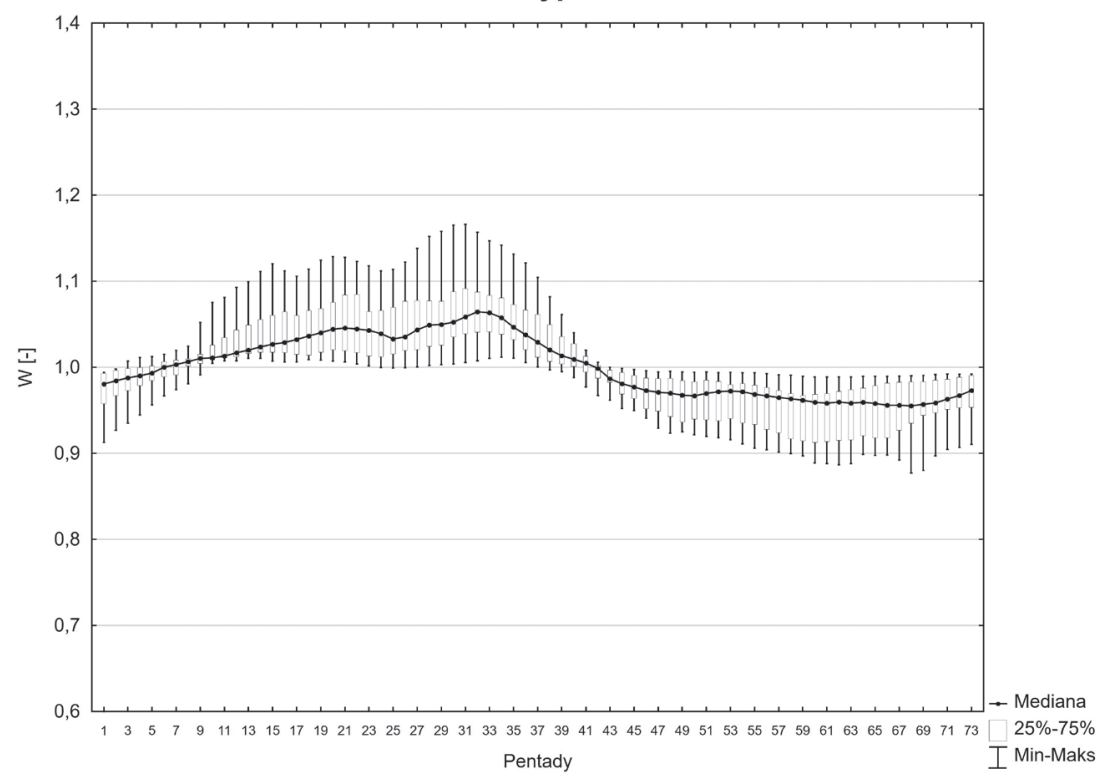

Ryc. 8. Zakres zmian pentadowych współczynników stanu wody jezior w typie 5

Fig. 8. Range of changes of pentad water stage coefficients in type 5 lakes 


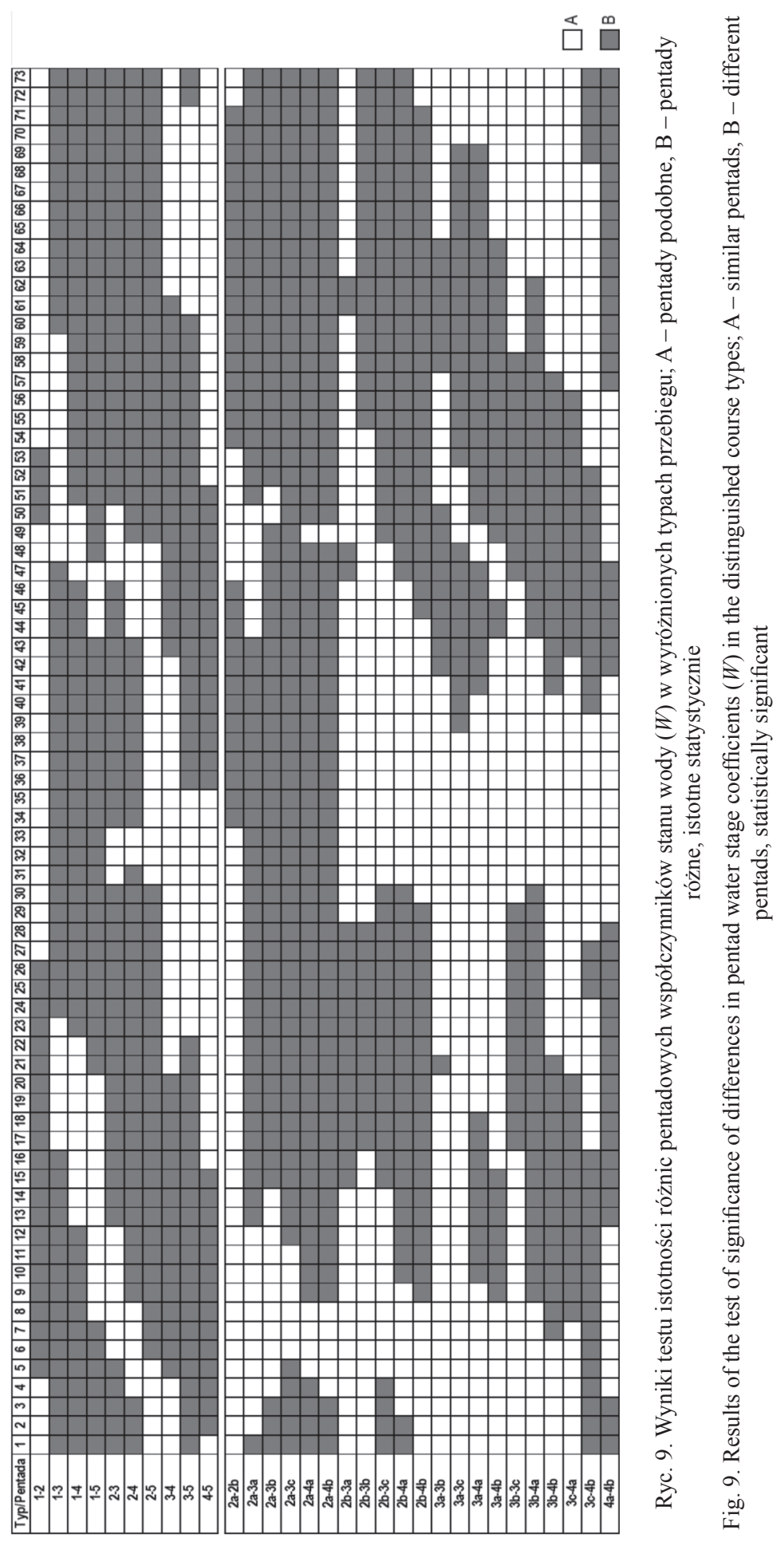


Podtypy 2a i 2b różnią się od siebie istotnie statystycznie wartościami $W$ od drugiej połowy kwietnia do drugiej połowy czerwca oraz od drugiej połowy lipca do drugiej połowy października, przez prawie połowę roku hydrologicznego $(42,5 \%)$. Odmienny przebieg współczynnika stanu wody jezior w podtypach 3a i 3b obserwuje się w połowie lutego, od drugiej połowy maja do pierwszej połowy lipca oraz w połowie sierpnia do połowy września (ryc. 9). Przebieg i wysokość współczynnika $W$ w podtypie $3 \mathbf{b}$ różni się istotnie statystycznie od współczynnika stanu wody w podtypie 3a w 23,3\% dni w roku. Na jeziorach podtypu 3c średni stan wody jest różny istotne statystycznie od średniego stanu wody jezior w podtypie 3a przez 135 dni w roku (37\%) od pierwszej połowy maja do drugiej połowy czerwca oraz od drugiej połowy lipca do pierwszej połowy października. $\mathrm{W}$ czasie trwania niskich stanów wody w podtypie 3c obserwuje się znacznie niższe wartości $W$ niż w podtypie 3a (ryc. 6). Istotne statystycznie różnice pomiędzy wartościami współczynnika $W$ w podtypach 3c i 3b obserwuje się przez 34\% dni w roku (druga połowa stycznia do drugiej połowy marca oraz $\mathrm{w}$ drugiej połowie czerwca do połowy sierpnia).

Współczynniki stanu wody jezior w podtypach 4a i 4 b różnią się od siebie istotnie statystycznie w pierwszej połowie listopada, w pierwszej połowie stycznia do drugiej połowy marca, w drugiej połowie maja do drugiej połowy czerwca oraz od pierwszej połowy sierpnia do końca października (w pentadach: 1-3, 13-28, 42-47, 57-73), w sumie przez 58\% dni w roku.

\section{PODSUMOWANIE}

W pracy wyznaczono 5 głównych typów przebiegu pentadowych współczynników stanu wody na badanych jeziorach. Na drugim poziomie grupowania wyznaczono 7 podtypów (dla grupy 2, 3 oraz 4). Wyznaczone typy przebiegu przeciętnych współczynników stanu wody różnią się od siebie, ale zazwyczaj nie wykazują zależności przestrzennych (ryc. 3 i 9). Wyjątek stanowią jeziora należące do typu 1 przebiegu współczynnika $W$. Są to jeziora przybrzeżne (Jamno, Łebsko, Gardno, Bukowo), które poprzez przetoki mają bezpośrednie połączenie z Morzem Bałtyckim, dlatego są pod jego bardzo dużym wpływem (Girjatowicz 2008, 2011; Burandt i in. 2017; Kobus i in. 2017). Natomiast jezioro Druzno ma pośrednie połączenie z morzem przez rzekę Elbląg i Zalew Wiślany (Fac-Beneda 2013). Jeziora zaliczone do podtypu 2a (Szczytno i Charzykowskie) charakteryzują się wyraźnie odmiennym terminem występowania wysokich stanów wody w okresie letnio-jesiennym. Jeziora te są oddalone od siebie w linii prostej o około $20 \mathrm{~km}$, są to jeziora przepływowe, a głównym ciekiem, który je zasila jest rzeka Brda. W przyszłych badaniach należałoby przeanalizować przepływy Brdy oraz rozmieszczenie urządzeń hydrotechnicznych znajdujących się na rzece. Przyczyn występowa- 
nia wysokich stanów wody znacznie później niż na większości jezior w Polsce można również doszukiwać się, badając warunki fizjograficzne zlewni jezior. Należy podkreślić pewną odmienność jezior w podtypie $2 \mathbf{b}$. $Z$ wcześniejszych badań wynika, że charakteryzują się one wysokimi średnimi rocznymi amplitudami stanów wody (Plewa i in. 2017). W porównaniu z jeziorami w typach 1 i 2 pozostałe jeziora różnią się istotnie statystycznie wysokością pentadowych współczynników stanu wody (ryc. 9). Jeziora są położone na wszystkich pojezierzach badanego obszaru.

Przeprowadzone badania potwierdziły, że współczynnik stanu wody, także w przypadku badań limnologicznych, może być dobrym narzędziem w analizie reżimu stanów wody w przeciętnym cyklu rocznym. Stwierdzenie braku zróżnicowania przestrzennego w położeniu wyróżnionych typów jezior wskazuje na duże znaczenie indywidualnych cech jezior i ich zlewni w kształtowaniu cech reżimu hydrologicznego. Brak zróżnicowania przestrzennego został zauważony również w badaniach Borowiaka (2000). Sugeruje on, że w dużej mierze cechy reżimu stanów wody są kształtowane na poziomie warunków lokalnych. Choiński (2007) zwraca uwagę na decydujący wpływ podłoża antropogenicznego na zmiany stanów wody. Podobne wnioski zostały wyciągnięte również podczas analiz innych badaczy (Bajkiewicz-Grabowska 2001; Górniak 200; Dąbrowski 2001, 2002, 2004). Stąd w kolejnych etapach badań należy zweryfikować charakter zlewni, zbadać korelacje parametrów morfometrycznych jezior i zlewni z amplitudami stanów wody jezior oraz określić wpływ działalności człowieka na zmiany cech reżimu stanów wody.

\section{LITERATURA}

Bajkiewicz-Grabowska E., 2001: Trends in water level changes in the lakes of North-eastern Poland, Limnol. Rev., 1, 3-14.

Borowiak D., 2000: Rezimy wodne i funkcje hydrologiczne jezior Niżu Polskiego, Kat. Limnol. UG, Gdańsk.

Burandt P., Kobus S., Sidoruk M., Glińska-Lewczuk K., 2017: Hydrographic and hydrological characteristick part I: Liwia Łuża, Resko Przymorskie, Jamno, Kopań and Wicko, [w:] K. Obolewski, A. Astel, R. Kujawa, Hydroecological Determinants of Functioning of Southern Baltic Coastal Lakes, Wyd. Nauk. PWN, Warszawa.

Chlost I., Cieśliński R., 2005: Change of level of waters Laske Łebsko, Limnol. Rev., 5, 17-26.

Choiński A., 1985: Wybrane zagadnienia z limnologii fizycznej Polski, Wyd. Nauk. UAM, Poznań.

Choiński A., 2006: Katalog jezior Polski, Wyd. Nauk. UAM, Poznań.

Choiński A., 2007: Limnologia fizyczna Polski, Wyd. Nauk. UAM, Poznań.

Dąbrowski M., 2001: Anthropogenic changes in the hydrographic system of Great Mazurian Lakes, Limnol. Rev., 1, 49-56.

Dąbrowski M., 2002: Changes in the water level of lakes in northeastern Poland, Limnol. Rev., $2,85-92$.

Dąbrowski M., 2004: Trends in changes of lake water levels in Pomeranian Lakeland, Limnol. Rev., 4, 75-80. 
Dąbrowski M., Węglarczyk S., 2005: Cyclical nature of fluctuations in the levels of lakes of Northern Poland, Limnol. Rev., 5, 61-67.

Elektroniczny podręcznik ptatystyki PL, Kraków, WEB: <http://www.statsoft.pl/textbook/stathome.html> [dostęp: 3.09.2018].

Fac-Beneda J., 2013: Charakterystyka hydrologiczna jeziora Druzno, [w:] C. Nitecki, Monografia jeziora Druzno, Wyd. Mantis, Olsztyn.

Girjatowicz J.P., 2008: Miesięczne i sezonowe charakterystyki poziomów wody wybranych polskich jezior przybrzeżnych, Inż. Mor. i Geotechn., 1, 27-32.

Girjatowicz J.P., 2011: Wpływ Morza Bałtyckiego na poziomy wód polskich jezior przybrzeżnych, Inż. Mor. i Geotechn., 18-22.

Górniak A., 2001: Natural and antropogenic changes in the water level of lakes of the Podlaskie Voivodeship, Limnol. Rev., 1, 125-130.

Górniak A., Piekarski K., 2002: Seasonal and multiannual changes of levels in lakes of Northeastern Poland, Pol. Journ. of Environmental Stud., 11, 4, 349-354.

Jańczak J., Choiński A., 1988: Wahania poziomów wody wybranych jezior Polski w latach 19561985, [w:] Z. Churski (red.), Naturalne i antropogeniczne przemiany jezior i mokradet w Polsce, Wyd. UMK, Toruń.

Kobus S., Sidoruk M., Burandt P., Glińska-Lewczuk K., 2017: Hydrographic and hydrological characteristick part II: Gardno, Dotgie Wielkie, Łebsko, Sarbsko and Ptasi Raj, [w:] K. Obolewski, A. Astel, R. Kujawa, Hydroecological Determinants of Functioning of Southern Baltic Coastal Lakes, Wyd. Nauk. PWN, Warszawa.

Kornaś M., Krauze G., 2010: Przyczyny wahania stanów wody jezior zlewni rzeki Drawa, [w:] A. Grześkowiak, B. Nowak (red.), Dynamika procesów przyrodniczych w zlewni Drawy i Drawieńskim Parku Narodowym, IMGW, PIB Oddz. w Poznaniu, Cent. Limnol, Pol. Tow. Geofiz. w Warszawie.

Marszelewski W., Pius B., Błoniarz W., Pestka J., 2016: Stany wody w jeziorach PN „Bory Tucholskie”, [w:] A. Choiński, M. Kochanowska, W. Marszelewski (red.), Przyroda abiotyczna Parku Narodowego „Bory Tucholskie”, Bogucki Wyd. Nauk., Poznań.

Pardé M., 1957: Rzeki, PWN, Warszawa.

Pasławski Z., 1975: Typologia hydrologiczna jezior Pojezierza Wielkopolskiego, Przegl. Geofiz., $20,4$.

Plewa K., Wrzesiński D., Baczyńska A., 2017: Przestrzenne i czasowe zróżnicowanie amplitud stanów wody jezior w Polsce w latach 1981-2015, Bad. Fizjogr., R. 8, Ser. A(A68), 115-126.

Plewa K., Wrzesiński D., Ptak M., 2015: Reziim stanów wody wybranych jezior Pojezierza Wielkopolsko-Kujawskiego, Bad. Fizjogr., R. 6, Ser. A(A66), 131-142.

Skibniewski L., 1954: Wahania poziomów zwierciadta wody większych jezior Pojezierza Pomorskiego i Mazurskiego, Przegl. Meteor., 7(3-4), 159-172.

Volchak A., Choiński A., Kirviel I., Parfomuk S., 2017: Spectral analysis of water level fluctuations in Belarusian and Polish lakes, Bull. of Geograph. Phys. Geograph. Ser., 12(1), 51-58.

Ward J.H., 1963: Hierarchical grouping to optimize an objective function, Journ. of the Am. Statist. Ass., 58(301), 236-244.

Wrzesiński D., Plewa K., 2016: Stability of the water levels regime on the lakes in Poland, Bad. Fizjogr., R. 7, Ser. A(A67), 305-316.

Wrzesiński D., Ptak M., 2016: Water level changes in Polish lakes during 1976-2010, Journ. of Geograph. Sc., 26(1), 83-101.

Wrzesiński D., Ptak M., Plewa K., 2018: Effect of the North Atlantic Oscillation on water level fluctuations in lakes of northern Poland, Geograph. Polon., 91(2), 243-259. 